\title{
Pasihan Mataraman: Bentuk dan Struktur Gerak Tari Asmara Hastungkara
}

\author{
Selo Argananto ${ }^{\mathrm{a}, 1, *}$, Nanik Sri Prihatini ${ }^{\mathrm{b}, 2}$ \\ a Jurusan Tari Fakultas Seni Pertunjukan Institut Seni Indonesia Surakarta \\ b Jurusan Tari Fakultas Seni Pertunjukan Institut Seni Indonesia Surakarta \\ ${ }^{1}$ selo.argananto@gmail.com \\ * Penulis Korespondensi
}

Received 17 September 2021; accepted 11 Oktober 2021; published 3 November 2021

\section{ABSTRACT}

Research on the form of Pasih Asmara Hastungkara Dance by Slamet aims to describe the form and structure of the dance. This dance is considered fascinating because it is located in Surakarta but with a Yogyakarta style of movement. This study uses qualitative research methods, with data collection techniques carried out are observation, interviews, and literature study. It aims to obtain as much data as possible, then analyze and describe it in-depth to answer the problem of the form and structure of Slamet's Pasihan Asmara Hastungkara Dance. Form analysis uses the theoretical basis of Suzane K. Langer, then theoretically explained using Slamet's opinion to reveal its constituent elements. Furthermore, to analyze the structure, using the theory of Anya Peterson Royce, then grammatically described the arrangement of movements based on the opinion expressed by Ben Suharto.

The study results obtained an explanation of the form and structure of the Pasihan Asmara Hastungkara Dance by Slamet. The shape of the Pasihan Asmara Hastungkara Dance by Slamet cannot be separated from several of its constituent elements, namely dancers, motion, rhythm, expression, make-up, clothing, and the venue for the performance. Structurally, this dance movement consists of motion motifs, motion phrases, motion sentences, and groups of motion sentences. Overall, the costumes, variety, motion, accompaniment, and structure of the presentation show that Asmara Hastungkara Dance is a dance work with the Yogyakarta style. However, in the production, the impression is present in the Surakarta style pasihan dance due to the dancers' ability who have a Surakarta style dance background. In the muryani section, the clothing and beksan jogedan adopted the Surakarta style movements, which is a distinctive feature for the Pasihan Asmara Hastungkara Dance by Slamet.

\section{KEYWORDS}

Pasihan

Form

Structure of Dance

Tari Asmara

Hastungkara

This is an open access article under the CC-BY-SA license

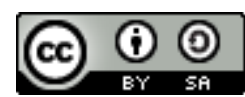

\section{Pendahuluan}

Jenis tari berdasarkan tema, terbagi menjadi tari keprajuritan, tari bertema fauna, tari permainan, tari religi dan tari percintaan. Tari percintaan sendiri terbagi menjadi tiga macam berdasarkan pola sajiannya yaitu tari tunggal, tari kelompok dan tari berpasangan atau pasihan (Maryono 2015, 12). Tari Asmara Hastungkara merupakan tari bergenre pasihan yang diciptakan oleh Slamet pada tahun 2018, yang terinspirasi dari salah satu cerita Menak yang berkembang di Yogyakarta. Cerita yang diambil adalah kisah percintaan yang dialami oleh Wong Ageng Jayengrana dengan Kelaswara. Kisah ini bercerita tentang cinta mereka yang suci dan sejati (Argananto 2021, 1). Kata asmara hastungkara sendiri berasal dari bahasa Jawa, yang terdiri atas kata asmara dan hastungkara. Asmara memiliki arti sengsem dan sih tresna atau dalam bahasa Indonesia adalah percintaan dan kasih sayang, sedangkan hastungkara berarti mulia, tunggal, dan sejati (Prawiroatmodjo 1994). Oleh karenanya, tari ini merupakan simbolisasi harapan bahwa pasangan hidup memiliki ikatan cinta yang tulus dan sejati.

Pembahasan ini akan berfokus pada bentuk tari dan struktur gerak Tari Asmara Hastungkara, yang diciptakan oleh Slamet. Pada awal penciptaannya, tari ini menggunakan dasar vokabuler gerak 
tari gaya Yogyakarta atau Mataraman, yang memiliki nilai dan kesan rasa rindu, marah, mesra, lelewa, sengsem, luwes, dan kenes (Argananto 2021, 1).

Permasalahan yang muncul pada penulisan ini adalah persoalan bentuk dan struktur tari Pasihan Asmara Hastungkara. Tari pasihan yang terinspirasi salah satu cerita Menak yang berkembang di Yogyakarta ini, menceriterakan kisah percintaan Wong Agung Jayengrana dengan Kelaswara. Berdasarkan bentuknya tari ini disajikan secara berpasangan putra dan putri. Penari putra menarikan tokoh yang berkarakter alus, dan penari putri menarikan tokoh yang berkarakter mbranyak.

Untuk membedah persoalan bentuk dan struktur tari pasihan Asmara Hastungkara ini, digunakan konsep yang ditawarkan oleh Suzane K. Langer yang menyatakan bahwa bentuk dalam pengertian yang paling abstrak adalah struktur artikulasi sebuah hasil kesatuan yang menyeluruh dari suatu hubungan berbagai faktor yang saling berhubungan, dan lebih tepatnya adalah sebuah teknik yang merakit aspek-aspek yang ada secara keseluruhan (Langer 1988, 15-16). Aspek-aspek yang dimaksud ini merupakan elemen-elemen pembentuk tari, yakni gerak, irama, ekspresi atau rasa, kostum, tempat pentas dan penari (Slamet 2016, 40). Mengenai struktur, kajian ini menggunakan prinsip yang diambil dari Antropologi Tari, bahwa strukur itu sendiri merupakan suatu hubungan antara seluruh bagian dan apapun yang terjadi serta berhubungan dengan sebuah tarian (Argananto 2021, 9). Dan bahwa pengorganisasian gerak dalam struktur tersebut dapat dianalisis berdasarkan empat tataran gramatikal yakni motif, frase, kalimat, dan gugus kalimat gerak (Suharto dalam Supriyanto 1999, 73).

\section{Metode}

Tulisan ini merupakan hasil penelitian dengan judul "Bentuk Tari Pasihan Asmara Hastungkara Karya Slamet", yang menggunakan metode penelitian kualitatif dengan bentuk deskriptif analitis. Penelitian tersebut melalui tahapan pengumpulan dan analisis data. Tahap pengumpulan data dilakukan dengan observasi langsung pada tahun 2018, saat pementasan karya tersebut di Pendapa ISI Surakarta, dan observasi tidak langsung melalui diskografi berupa video dokumentasi karya seni. Aktivitas pengumpulan data lainnya adalah studi pustaka untuk mendapatkan informasi penunjang kelengkapan penelitian ini, yakni mengenai sejarah tari pasihan, dan teori-teori yang mendukung pembahasan penelitiani ini. Kegiatan lainnya adalah wawancara, yang dilakukan kepada narasumber yang kompeten dan relevan yakni kepada koreografernya, penata gending, penari, penata rias dan busana, serta akademisi tari. Analisis data yang dilakukan dalam penelitian ini dengan metode komparatif, untuk menunjukkan bentuk dan struktur tari pasihan Asmara Hastungkara.

\subsection{Tahap Pengumpulan Data}

The length of the submitted paper is at least 3000 words and no more than 7000 words. The editor will consider if the article requires more than 7000 words. (one single space, $11 \mathrm{pt}$ font)

\subsection{Document Details}

\subsubsection{Abbreviations/Terms/Notations/Symbols}

The use of the abbreviation is permitted, but the abbreviation must be written in full and complete when it is mentioned for the first time and it should be written between parentheses. Terms/Foreign words or regional words should be written in italics. Notation should be brief and clear and written according to the standardized writing style. Symbols/signs should be clear and distinguishable, such as the use of number 1 and letter 1 (also number 0 and letter $\mathrm{O}$ ).

\subsubsection{Measurements}

For measurements use S.I Units (System International units). Measurement should be abbreviated (e.g. mm, kcal, etc.) in accordance the Style Manual for Biological Sciences and using the metric system. Do not begin sentences with a numerical figure. When heading a sentence, numbers should be spelled out.

\subsubsection{Section Headings}

Three levels of heading are allowed as follows:

- Level 1 (Heading 1 format) - 11pt, bold, left-justified 
- Level 2 (Heading 2 format) - 11pt, bold, left-justified

- Level 3 (Heading 3 format) - 11pt, bold italic, left-justified

\subsubsection{Body Text}

The body of the text is a set of body text paragraphs defined as follows:

- 11 pt Times New Roman

- Single space, defined as $12 \mathrm{pt}$

- Spacing after the heading is $3 \mathrm{pt}$

- Spacing before the new heading is $3 \mathrm{pt}$

\subsubsection{Bullets}

There are two levels of allowed bulleting:

- This is the first bullet level

- This is a sub-bullet level

\section{Hasil dan Pembahasan}

\subsection{Bentuk Tari Pasihan Asmara Hastungkara}

Penjelasan mengenai bentuk, perlu diulas secara jelas mengenai unsur-unsur pembentuk tari yakni gerak, irama, ekspresi atau rasa, kostum, tempat pentas, dan penari. Untuk lebih jelasnya akan dipaparkan berikut ini.

\subsubsection{Gerak}

Gerak merupakan media utama yang harus ada dalam sebuah tari. Peranan gerak yang sangat penting ini seringkali menjadi hal mendasar dan dijadikan sebagai pondasi atau dasar yang mampu memberi warna atau corak tersendiri dari suatu tari. Gerak tari seringkali muncul sesuai dengan interpretasi, dan latar belakang koreografer yang tentunya akan merujuk mengenai gaya, atau genre tari tersebut. Gaya dapat juga diartikan sebagai teknik dalam membawakan tari, sehingga menjadikan tari yang satu berbeda dengan tari yang lain. Pemilihan ragam gerak yang digunakan dalam suatu tarian juga sebagai penentu dari genre dan juga gaya suatu tari.

Tari Asmara Hastugkara memiliki karakter tokoh yang halus tetapi juga tegas. Hal ini terlihat dari pilihan ragam gerak yang digunakan. Tari ini menggunakan ragam-ragam gerak tari Yogyakarta seperti nggrudho, impur dan beberapa ragam gerak yang lain sehingga apabila dilihat secara visual gerak tari ini sudah jelas bergaya Yogyakarta atau Mataram dengan genre tari pasihan atau percintaan. Pemilihan dan penggunaan ragam gerak tari Yogyakarta ini dipengaruhi oleh faktor latar belakang pendidikan dan kesenimanan koreografer (Argananto 2021, 33).

\subsubsection{Irama dan Musik/Gendhing}

Irama dapat diartikan berbicara mengenai musik atau iringan yang mengiringi suatu tari. Selain itu juga berhubungan dengan persamaan tempo antara gerak dengan musik tari yang digunakan (Argananto 2021, 69). Pada tari Asmara Hastungkara terdapat perubahan-perubahan tempo yang terjadi di dalamya, di mana setiap gerak yang dilakukan memiliki ketukan yang tidak selalu sama atau tidak ajeg. Seperti contoh pada gerak kipat gajahan, di sana dapat dilihat bahwa tempo atau irama geraknya sedang. Akan tetapi berbeda pada saat melakukan nyamber, ataupun perangan. Gerak yang dilakukan pada bagian tersebut memiliki tempo yang cepat.

Terkait dengan irama gerak, terdapat beberapa istilah yakni pidakan yang berarti penggunaan teknik seleh gerak yang berhubungan dengan seleh gendhing. Secara teknis, pidakan menghubungkan antara ritme gerak dan irama gerak yang selaras dengan irama gendhing. Pidakan terdiri dari beberapa teknik yaitu midak, nujah, nggandul, dan tranjal (Argananto 2021, 70). Pada Tari Asmara Hastungkara, teknik yang digunakan yaitu midak, yang memiliki artian bahwa setiap gerakan yang dilakukan berakir bersamaan sengan seleh gendhing atau gong. 
Gendhing sebagai bentuk musik dan instrumen sebagai alat penghasil suara, serta suara yang ditimbulkan dari lagu gerongan yang dilantunkan oleh penggerong atau sindhen. Adapun susunan karawitan Tari Asmara Hastungkara adalah sebagai berikut.

- Pathetan nem (ada-ada atau gendhing pembuka)

- Srepeg Mataram 1 (maju gendhing)

- Ketawang Asmara (enjeran dan muryani busana)

- Kebar Astungkara (beksan kebar)

- Ketawang Mundur Beksan (mundur gendhing)

- Pathetan Nem (penutup).

\subsubsection{Ekspresi atau Rasa}

Ekspresi wajah dalam pertunjukan tari digunakan penari untuk membantu ekspresi gerak tubuh dalam rangka mengekspresikan totalistas emosi peran atau tokoh. Berdasarkan eksprei dari penari maka akan tampak suasana yang sedang dialami peran atau tokoh (Maryono 2015, 60). Ekspresi atau rasa yang disampaikan dalam sebuah tarian dapat pula dipertegas dengan pandengan atau pandangan mata. Pandangan mata bukan sekedar padangan mata seorang penari untuk melihat situasi sekitar. Melainkan mengandung suatu isi yang dapat mencerminkan suasana jiwa dan karakter tokoh yang dibawakan. Jadi pandengan bukan merupakan tehnik luar saja tetapi erat sekali hubungannya dengan penjiwaan tari yang terkandung dalam filsafat joged Mataram. Dalam tingkat pertama, pandengan ini akan mampu membentuk polatan atau ulat (mimik). Pada tingkat berikutnya mampu mengungkapkan pasemon (semu). Pasemon adalah pancaran yang mengekspresikan getaran jiwa. Jika seorang penari mampu menghayati pandengan secara penuh, maka akan mampu mengungkapkan rasa sengsem, marah, gembira, cinta dan sebagainya melalui pandengan (Wibowo 1981, 60).

Tari Asmara Hastungkara merupakan tarian yang memiliki perpaduan rasa, yaitu marah dan senang. Pengungkapan kemarahan ini dimunculkan pada saat maju beksan yaitu digambarkan dengan gerakan perang. Bagian ini ekspresi yang dimunculkan yaitu diam, tegas, dan marah. Ketika mulai peralihan menuju kebar pertama maka sudah terjadi peralihan ekspresi yaitu ekspresi senang, gembira dan penuh rasa cinta. Pandangan mata penari putra tegas, tajam tetapi tidak tengadah, karena mengambarkan perwatakan dari seorang Jayengrana yang berwibawa, gagah, tetapi halus pembawaannya. Kemudian, pandangan mata penari putri dalam membawakan karakter Kelaswara sedikit lebih menunduk dari penari putra karena sebagai perumpamaan kesopanan dirinya terhadap seorang laki-laki, serta kelembutan dirinya sebagai perempuan meskipun juga piawai dalam berperang (Argananto 2021, 77).

\subsubsection{Tata Rias, Busana, dan Kostum}

Dalam pementasan suatu tari, tentu tidak lepas dari unsur tata rias dan juga busana yang dikenakan oleh penari. Rias dalam seni pertunjukan tari tidak sekadar mempercantik dan memperindah diri penari, namun lebih dari itu berfungsi seagai pendukung untuk menguatkan ekspresi peran tokoh yang dibawakan. Dengan kata lain, tat arias dapat memberikan ekspresi secara visual. Busana memiliki peranan untuk mengarahkan penonton pada pemahaman mengenai peran atau tokoh yang dbawakan oleh penari dalam sajian pertunjukan tari tersebut. busana tari adalah untuk mendukung tema atau isi tari dan untuk memperjelas peran-peran dalam suatu sajian tari. Busana atau kostum yang baik bukan hanya sekedar untuk menutupi tubuh semata, melainkan juga harus dapat mendukung desain ruang pada saat penari sedang menari (Jazuli 1994, 17). Di samping itu, busana selain memiliki bentuk atau mode juga memiliki warna yang bermakna sebagai simbol dalam pertunjukan. Jenis simbol bentuk dan warna busana para penari yang dimaksudkan memiliki peran sebagai identitas, karakteristik, dan ekspresi estetis (Maryono 2015, 62).

Tata rias dan busana Tari Asmara Hastungkara terbagi menjadi tiga komponen yaitu tata rias wajah, tata rambut dan tata busana. Tata rias wajah yang digunakan dalam tari ini yaitu rias korektif cantik untuk penari putri dan rias tampan untuk penari putra (Argananto 2021, 79). Rias korektif adalah riasan dengan tujuan mempertegas garis-garis wajah dan tidak untuk membentuk karakter 
tertentu (Jazuli 1994, 20). Hal ini dipilih karena Kelaswara adalah seorang putrid yang berparas cantik, sedangkan Jayengrana memiliki wajah yang tampan dan rupawan. Meskipun rias korektif, namun riasan ini juga dapat digolongkan rias karakter, karena merujuk pada seorang tokoh (Argananto 2021, 80).

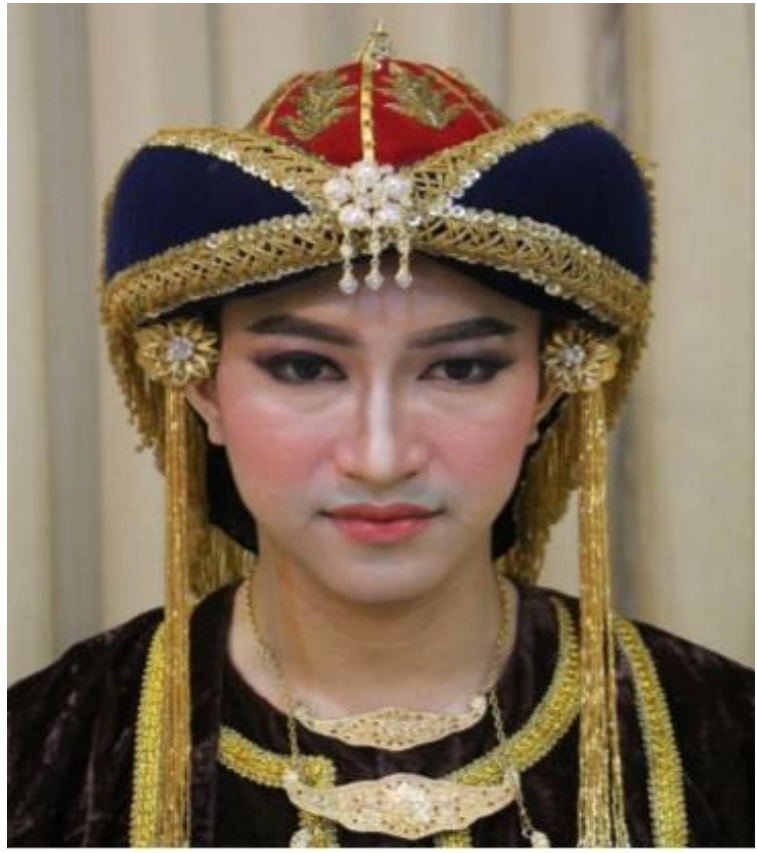

Gambar 1. Rias Penari Putra Tokoh Jayengrana

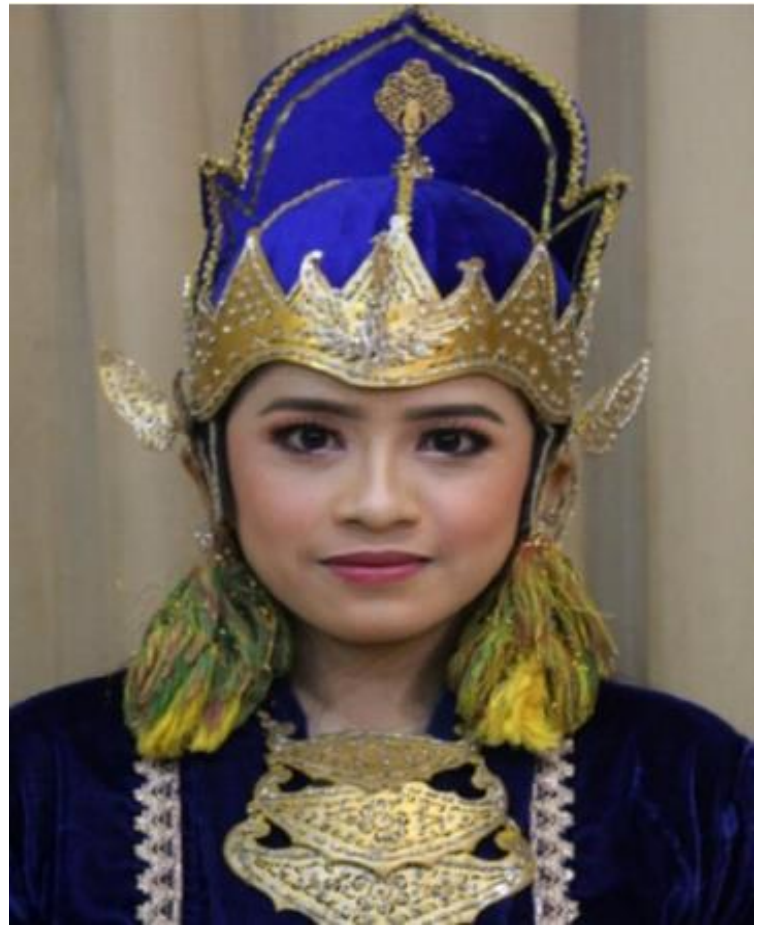

Gambar 2. Rias Penari Putri Tokoh Kelaswara 
Tata rambut yang digunakan Tari Asmara Hastungkara adalah menggunakan irah-irahan puthutan utuk penari pria, penari putri menggunakan irah-irahan songkok putri dengan rambut digerai. Sumping, digunakan di kanan dan kiri telinga. Untuk penari putri sumping yang digunakan memiliki gombyok yang terbuat dari benang wol berwarna hijau dan oranye. Pada penari putra gombyok terbuat dari payet atau gem. Bros, hiasan yang terbuat dari logam dan dihiasi permata digunakan di tengah irah- irahan penari pria (Argananto 2021, 81).

Tata busana yang digunakan yaitu baju berbahan bludru lengan panjang. Pemilihan warna dan motif busana tidak terlalu terikat dengan sebuah patokan. Warna yang digunakan dalam pementasan ini adalah merah hati dan juga biru. Tata busana Tari Asmara Hastungkara berdasarkan tempat penggunaannya diklasifikasikan menjadi dua, yakni tungkai dan badan. Busana badan terdiri dari kalung penanggalan susun, baju bludru panjang, terbuat dari bahan kai bludru dengan hiasan pita emas, udhet atau sampur, slepe, kamus, timang, pendhing, tagen, keris, oncen, kelat bahu ngangrangun. Tata busana tungkai terdiri dari bara, celana panji, sinjang atau jarik (Argananto 2021, 82).

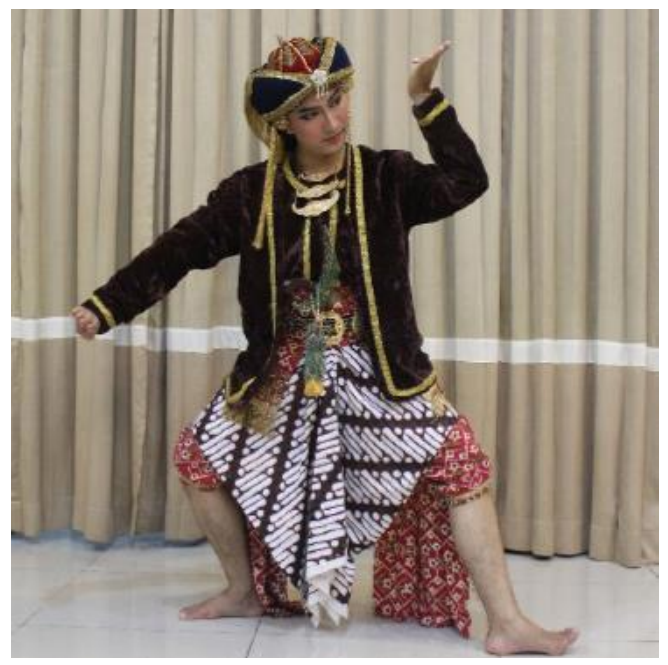

Gambar 3. Busana Penari Putra Tokoh Jayengrana

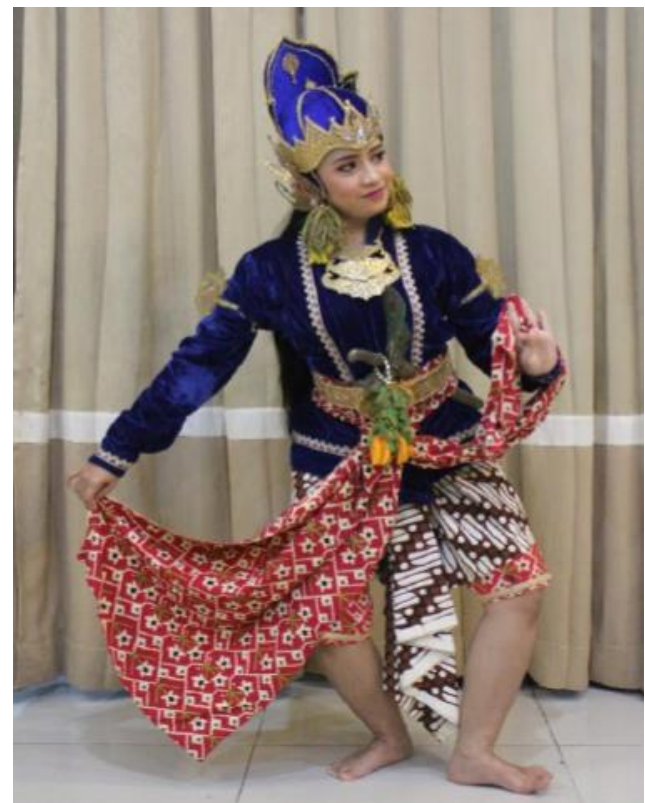

Gambar 4. Busana Penari Putri Tokoh Kelaswara 


\subsubsection{Tempat Pentas}

Tempat pentas atau sering dikenal dengan istilah panggung, merupakan tempat yang digunakan untuk menggelar sebuah karya pertunjukan di depan para penonton. Panggung merupakan salah satu hal yang cukup penting keberadaan dan pengaruhnya dalam sebuah pertunjukan. Panggung pertunjukan diklasifikasikan menjadi dua, yakni panggung tertutup dan panggung terbuka. Panggung tertutup terdiri atas panggung proscenium, pendapa, tobong atau panggung keliling, yang ketiganya dapat digunakan untuk pementasan tari kelompok, tunggal, drama tari, dan tari pasangan. Kemudian panggung terbuka, dapat berupa halaman yang sifatnya alami, dapat dipergunakan untuk pertunjukan tari rakyat, garapan tari kolosal, karnaval, dan lain sebagainya. Selain dua jenis tersbeut, masih dapat disebutkan yakni panggung resepsi, yang merupakan pertunjukan yang digelar dalam hajatan-hajatan tertentu seperti pernikahan, ulang tahun, dan lain sebagainya (Maryono 2015, 67).

Tari Asmara Hastungkara dipentaskan di sebuah pendapa. Meskipun demikian sebenarnya tari ini tidak terikat oleh tempat pementasan atau dapat menyesuaikan kondisi. Sebenarnya tari ini memiliki kebebasan untuk tempat pementasan, atau tidak terikat pada tempat tertentu. Karena memang sifatnya yang menghibur, menyambut tamu pada sebuah hajatan pernikahan. Oleh karena itu, tari ini dapat disajikan di sebuah pendapa atau menyesuaikan tempat berlangsungnya acara. Dengan kata lain, tari ini dapat disajikan dalam ruang pentas berupa panggung tertutup dan panggung resepsi (Argananto 2021, 92). Bentuk penataan panggung pada tari Asmara Hastungkara ini tidak menambahkan ornament sebagai background panggung. Akan tetapi menempatkan pengrawit tepat di belakang penari. Hal ini terinspirasi pementasan yang dilakukan di Karaton Yogyakarta.

\subsubsection{Penari}

Penari berperan secara langsung untuk menyajikan tari di atas panggung dan disaksikan oleh penonton. Kemampuan penari dalam menyajikan karakter atau genre tari yang dibawakan sangat diperlukan. Pada tari Asmara Hastungkara ini penari dituntut mampu menampilkan nilai moral yang ada di dalamnya melalui karakter tokoh yang dipilih. Tari ini disajikan dengan jumlah penari yaitu dua orang, yang terdiri dari laki-laki dan perempuan. Penari putra merepresentasikan bahwa dirinya adalah Jayengrana yang memiliki karakter putra alus yaitu sederhana (karakter tenang, kalem), tampan, romantis, namun tetap tegas ketika berperang. Penari putri merepresentasikan diri sebagai Kelaswara yang memiliki karakter putri lanyap tanggung. Karakter ini menggambarkan seorang putri yang cantik, lincah dengan pandangan setengah tegap (Argananto 2021, 33).

\subsection{Struktur Tari Asmara Hastungkara}

Struktur dalam tari adalah seperangkat tata hubungan antara karakteristik gerak yang ada dalam sebuah tari. Karakteristik dapat mewakili gaya yang diacu serta keunikan yang terdapat dalam sebuah karya tersebut (Suharto dalam Wardhani 2009, 40). Dalam mengkaji struktur gerak tari Asmara Hastungkara, digunakan pendekatan struktur gramatikal, sebagaimana dilakukan dalam kajian linguistik.

Pengorganisasian gerak dapat dianalisis berdasarkan empat tataran gramatikal yaitu motif gerak, frase gerak, kalimat gerak, dan gugus kalimat gerak. Motif gerak merupakan satuan terkecil dari sebuah tari, yang berisi pola gerak tertentu dari rangkaian sikap atau gerak. Frase gerak merupakan hasil rangkaian dari beberapa motif gerak. Frase gerak sendiri dapat terdiri dari sebuah motif gerak saja atau beberapa motif gerak sekaligus, tetapi baru untaian gerak yang utuh dalam satu tatanan kalimat gerak (Argananto 2021, 94). Dengan demikian dapat diartikan bahwa kalimat gerak merupakan kesatuan dari frase yang sudah dirangkai dan selesai dalam satu periode. Kalimat gerak juga dapat terdiri atas satu atau beberapa frase sekaligus yang berakhir seirig dengan selesainya irama musik yang ditandai oleh seleh irama atau bunyi gong, kempul, kethuk, dan kenong. Kemudian gugus kalimat gerak adalah kata lain dari sekelompok kalimat gerak yang saling berkaitan karena memiliki ciri tertentu serta keutuhan kelompok, baik segi pola iringan maupun pola geraknya (Supriyanto 1999, 74). pengorganisasian gerak dapat dianalisis berdasarkan empat tataran gramatikal yaitu motif gerak, frase gerak, kalimat gerak, dan gugus kalimat gerak. Motif gerak merupakan satuan terkecil dari sebuah tari, yang berisi pola gerak tertentu dari rangkaian sikap atau gerak. Frase gerak merupakan hasil rangkaian dari beberapa motif gerak. Frase gerak sendiri dapat terdiri dari 
sebuah motif gerak saja atau beberapa motif gerak sekaligus, tetapi baru untaian gerak yang utuh dalam satu tatanan kalimat gerak. Untuk mengetahui uraian struktur Tari Asmara Hastungkara secara jelas, maka penulis membagi menjadi dua yaitu struktur sajian dan struktur gerak.

\subsubsection{Struktur Sajian Tari}

Tari Asmara Hastungkara, dalam penyajiannya terbagi menjadi empat bagian atau adegan yaitu maju gendhing, beksan enjeran, muryani busana, dan kebar jogedan. Masing- masing bagian memiliki ceritanya sendiri, namun masih dalam tataran batasan cerita yang sama.

- Adegan satu, yaitu maju gendhing sebagai pembuka tarian. Pada adegan ini, berisi tembangan dan diteruskan dengan adegan perang. Pada dasarnya, adegan ini menggambarkan pertemuan pertama sekaligus peperangan yang dialami oleh Wong Agung Jayengrana dengan Dewi Kelaswara. Penggambaran pertentangan gejolak hati antara kebencian dalam berperang dengan indahnya rasa kasmaran dalam adegan ini diwujudkan dengan perang tubrukan dan juga ngelus sebagai simbol kasih.

- Adegan dua, menggambarkan sepasang kekasih yang sedang berkenalan dan mendalami satu sama lain. Dalam adegan ini disebut enjeran yang tersusun dari motif gerak nggrudha, kipat ajahan, pendhapan, kenceng encot, dan gidrah.

- Adegan tiga berisi muryani busana. Gerak adegan ini menggambarkan dua orang yang sedang berhias diri berisi atrap jamang, lilingan ingsetan, tasikan, dan miwir rikma.

- Adegan empat kebar jogedan. Pada adegan ini berisi gerak-gerak yang mewakili kegembiraan dan kebahagiaan sepasang kekasih. Dalam bagian ini juga sekaligus terdapat mundur gendhing yang ditandai dengan kanthen asta kemudian srisig menuju gawang awal dan melakukan sembahan.

\subsubsection{Struktur Gerak Tari}

Ragam gerak Tari Asmara Hastungkara seperti yang dijelaskan pada pembahasan sebelumnya, sebenarnya terdiri dari beberapa unsur yang mendukung terjadinya gerak tersebut. Tubuh yang digunakan sebagai instrumen terbagi menjadi empat bagian yaitu kepala, badan, tangan, kaki. Masing- masing bagian sendiri terbagi menjadi dua yaitu unsur sikap dan unsur gerak.

Tabel 1. Struktur Gerak Tari Asmara Hastungkara

\begin{tabular}{|c|c|c|}
\hline \multirow{2}{*}{$\begin{array}{c}\text { Instrumen } \\
\text { Tubuh }\end{array}$} & \multicolumn{2}{|c|}{ Unsur } \\
\hline & Sikap & Gerak \\
\hline Kepala & $\begin{array}{l}\text { - Jejeg atau lurus: wajah menghadap ke } \\
\text { depan dengan posisi kepala tegak. } \\
\text { Tolehan: posisi kepala menghadap ke } \\
\text { kiri atau ke kanan }\end{array}$ & $\begin{array}{l}\text { - Pacak gulu: dari sikap jejeg, kepala } \\
\text { dimiringkan ke kanan kemudian ke } \\
\text { kiri dengan lintasan geraknya } \\
\text { membuat lingkaran kecil pada } \\
\text { dagu, kemudian kembali pada sikap } \\
\text { semula } \\
\text { - Noleh: perpindahan arah hadap } \\
\text { pandangan menurut arah hadap } \\
\text { muka }\end{array}$ \\
\hline Badan & $\begin{array}{l}\text { Ndegeg: badan dalam sikap tegak lurus, } \\
\text { dilakukan dengan mengencangkan tulang } \\
\text { belakang, dan dada sedikit dibusungkan } \\
\text { Leyekan: sikap badan condong ke } \\
\text { samping kanan atau kiri }\end{array}$ & $\begin{array}{l}\text { - Ngleyek: proses gerak } \\
\text { berpindahnya badan dari condong } \\
\text { kanan menjadi condong kiri } \\
\text { ataupun sebaliknya } \\
\text { Ngoyog atau hoyog: proses } \\
\text { memindah posisi badan dari kiri ke } \\
\text { kanan dan sebaliknya. Gerak ini } \\
\text { dilakaukan tanpa merubah posisi } \\
\text { tubuh, yang diperlukan adalah } \\
\text { kekuatan lutut untuk menopang } \\
\text { badan karena tidak berubah hanya } \\
\text { saja kaki melakukan gerak } \\
\text { ingsetan untuk menjaga }\end{array}$ \\
\hline
\end{tabular}




\begin{tabular}{|c|c|c|}
\hline \multirow{2}{*}{$\begin{array}{c}\text { Instrumen } \\
\text { Tubuh }\end{array}$} & \multicolumn{2}{|c|}{ Unsur } \\
\hline & Sikap & Gerak \\
\hline & & keseimbangan tubuh \\
\hline Tangan & $\begin{array}{l}\text { - Ngithing: jari tengah dan ibu jari } \\
\text { bersentuhan, sedangkan jari yang lain } \\
\text { ditekuk ke arah dalam telapak tangan } \\
\text { Ngruji: jari-jari dirapatkan dengan posisi } \\
\text { tegak lurus menghadap ke atas, ibu jari } \\
\text { ditekuk ke arah dalam } \\
\text { - Nyempurit: pergelangan ditekuk berdiri, } \\
\text { ibu jari dan jari tengan disatukan } \\
\text { ujungnya membentuk seperti lingkaran } \\
\text { yang tidak sempurnya. Jari telunjuk } \\
\text { ditempelkan antara jari tengah dan ibu } \\
\text { jari, sedagkan yang lain ditekuk } \\
\text { Ngepel: jari tengah, manis dan telunjuk } \\
\text { dirapatkan dan ditekuk ke dalam } \\
\text { menyentuk telapak tangan, sedangkan } \\
\text { kelingkin dan ibu jari ditekuk tetapi lebi } \\
\text { menonjol dari jari yang lain } \\
\text { Sembahan: kedua telapak tangan } \\
\text { dirapatkan, ibu jari menyentuh hidung, } \\
\text { empat jari lainnya menghadap ke depan } \\
\text { Malangkerik: jari ngepel disentuhkan di } \\
\text { pinggang } \\
\text { Njimpit sampur: jari ngithing, dengan } \\
\text { menyelipkan ujung sampur di antara jari } \\
\text { tengahdan ibu jari }\end{array}$ & $\begin{array}{l}\text { - Ukel: ukel memiliki beberapa jenis } \\
\text { yaitu ukel jugag dengan } \\
\text { pelaksanaannya tangan ditekuk, } \\
\text { pergelangan tangan diputar ke luar, } \\
\text { kemudian direnggangkan dan } \\
\text { diputar lagi. Kemudian ukel utuh } \\
\text { yang dilakukan dengan cara } \\
\text { menekuk tangan lalu diputar, } \\
\text { direggangkan, ditekuk lagi da } \\
\text { diputar lagi melalui sisi sebelah } \\
\text { dalam. Ukel tawing yaitu } \\
\text { melakukan ukel utuh di sebelah } \\
\text { telinga } \\
\text { Ngembat: sikap lurus kemudian } \\
\text { ditekuk sedikit lalu kembali ke } \\
\text { sikap lurus denga memberikan } \\
\text { tekanan } \\
\text { Cathok atau nyathok: dari sikap } \\
\text { njimpit kemudian tangan } \\
\text { direnggangkan atau jari-jari dibuka } \\
\text { kemudian melakukan ukel utuh } \\
\text { tetapi penuh dengan tekanan } \\
\text { Seblak: tangan mengurut atau } \\
\text { mlurut sampur dari pangkal sampai } \\
\text { dengan tangan menjadi posisi lurus, } \\
\text { saat sudah lurus kemudian jari-jari } \\
\text { diberitekanan untuk membuang } \\
\text { sampur }\end{array}$ \\
\hline Kaki & $\begin{array}{l}\text { - } \quad \text { Nylekenthing: jari-jari kaki dikencangkan } \\
\text { dan diangkat menjadi tegak lurus ke atas } \\
\text { - Jinjit: tumpuan terletak pada telapak kaki } \\
\text { bagian depan } \\
\text { - Tanjak: tungkai posisi mendhak, dengan } \\
\text { salah satu kaki kanan dibuka empat puluh } \\
\text { lima drajat, sedangkan kaki kiri } \\
\text { diluruskan ke samping sejajar ibu jari } \\
\text { kanan dan dibuka selebar bahu untuk } \\
\text { tanjak putra, untuk tanjak putri kaki kiri } \\
\text { berada ditengah kaki kanan. Gerak ini } \\
\text { adalah tanjak kiri, untuk kebalikannya } \\
\text { adalah tanjak kanan } \\
\text { Mendhak: kaki merendah dengan lutut } \\
\text { terbuka } \\
\text { Jengkeng jeblos: duduk dengan tumpuan } \\
\text { kaki yang menapak, kaki kanan ditekuk } \\
\text { ke belakang lutut menyentuh lantai, sikap } \\
\text { jinjit di samping belakang dan posisi } \\
\text { pantat berada di tengah antara kaki kiri } \\
\text { dan kanan }\end{array}$ & $\begin{array}{l}\text { Gedrug: kaki yang satu menapak, } \\
\text { kaki yang lain dihentakkanpada } \\
\text { lantai dengan gajul atau kaki bagian } \\
\text { depan, di belakang kaki yang } \\
\text { menapak } \\
\text { Encot: dari sikap awal, mumbul } \\
\text { lalu kembali ke sikap awal dengan } \\
\text { agak mentul atau membat } \\
\text { Seredan: gerakan membuat seperti } \\
\text { huruf s menggunakan salah satu } \\
\text { ujung kaki yang diawali dari kaki } \\
\text { yang napak kemudian melewati } \\
\text { samping dengan dilanjutkan gedrug } \\
\text { Mancat: kaki yang satu napak, kaki } \\
\text { yang lain napak agak jinjit di depan } \\
\text { kaki yang satu dengan agak ditekan } \\
\text { Srisig: lari kecil-kecil dengan sikap } \\
\text { badan tegak dan kaki berdiri sejajar } \\
\text { agak jinit, lutut agak menekuk } \\
\text { Kengser: kaki berjajar, sikap } \\
\text { mendhak kemudian telapak kaki kiri } \\
\text { bagian depan diingsut ke kanan dan } \\
\text { dilakukan dengan cepat }\end{array}$ \\
\hline
\end{tabular}

Suatu bentuk tari pada dasarnya terdiri dari beberapa komponen gerak atau serangkaian gerak terkecil sampai dengan gerak yang terbesar seperti halnya disebutkan di atas. Struktur itu sendiri sebenarnya bukanlah suatu urutan akan tetapi sebuah tata hubungan yang saling keterkaitan antara gerak satu dengan lainnya, sehingga tersusun menjadi sebuah sajian. Atas dasar paparan tersebut, maka dapat ditegaskan bahwa gerak Tari Asmara Hastungkara dapat digolongkan menjadi. 
- Gerak utama atau gerak pokok, yang terdiri dari sembahan, ulap-ulap, nggrudha, kipat gajahan, impur dewa, impur, atrap jamang, atrap sumping, tasikan, lilingan, nitir, thinthing, lumaksana, lembehan, mbat-mbat asta, engkrang, dan ngaras.

- Gerak penghubung yaitu yang menghubungkan antara gerak pokok satu ke gerak pokok selanjutnya. Gerak tersebut terdiri dari srisig, sendhi, pendapan, kanthen, dan pangkat nyamber, gidrah.

- Gerak mandheg yaitu gerak yang dilakukan dengan tidak berpindah tempat, terdiri dari gerak sembahan jengkeng, ulap-ulap, nggrudha, kipat gajahan, impur, impur dewa, tasikan, atrap jamang, atrap sumping, sendhi, liligan, thinthing encot, dan mbat- mbat asta.

- Gerak milir yaitu gerak yang dilakukan sambil berjalan atau dapat berpindah tempat terdiri dari gerak srisig, pendapan, lumaksana, lembehan, thinthing, dan nitir.

Pada dasarnya Tari Asmara Hastungkara dapat dikatakan sebagai serapan tari gaya Yogyakarta karena menggunakan ragam gerak tari gaya Yogyakarta, tetapi tari ini juga memiliki kesan seperti tari gaya Surakarta. Hal ini disebabkan karena Tari Asmara Hastungkara memiliki karakteristik yang berbeda dengan tari gaya Yogyakarta pada umumnya. Ragam gerak yang digunakan merupakan ragam gerak gaya Yogyakarta, namun dalam pelaksanaanya terpengaruh dengan gaya Surakarta. Selain pelaksanaan gerak, kesan gaya Surakarta juga disebabkan dengan adanya gerak yang diadopsi dari tari berpasangan gaya Surakarta. Gerak yang dimaksud adalah

- Gerak lilingan

- Gerak kipat cathok

- Gerak kanthen asta encot

- Gerak ngaras

Adanya gerak serapan ini dimaksudkan agar dapat menguatkan tema percintaan yang selama ini belum ada dalam tari gaya Yogyakarta. Meskipun terdapat ragam gerak tari Surakarta, tari ini tetap didominasi dengan ragam gerak tari gaya Yogyakarta yaitu

- Jengkeng jeblos, sembahan

- Gerak pendapan

- Gerak nggrudha

- Gerak kipat gajahan

- Gerak thinthing

- Gerak sendi

- Gerak impur

- Gerak gidrah

- Gerak impur dewa

- Gerak atrap sumping

Selain gerak di atas, terdapat pula ragam gerak yang secara visual sama antara gaya Yogyakarta dengan gaya Surakarta hanya berbeda cara penerapan atau pelaksanaannya. Gerak tersebut adalah

- Gerak tasikan dalam tari gaya Yogyakarta dilakukan tanpa merubah posisi tangan kiri, yaitu jari-jari tetap menghadap ke luar. Sedangkan gaya Surakarta tangan kiri dirotasi ke arah dalam dan luar setiap hitungan. 
- Gerak atrap jamang dalam tari gaya Yogyakarta posisi telapak tangan kiri sedikit dihadapkan ke dalam, sedangkan gaya Surakarta telapak tangan dihadapkan ke bawah. Selain itu ingsetan dalam tari gaya Yogyakarta hanya dilakukan pada peralihan antara gerak lamba dan ngracik

\section{Kesimpulan}

Bentuk Tari Pasihan Asmara Hastungkara tidak lepas dari beberapa elemen-elemen pembentuk nya yaitu penari, gerak, irama, ekspresi, tata rias dan busana serta tempat pementasan. Secara struktural, gerak tari ini terdiri dari motif gerak, frase gerak, kalimat gerak, dan gugus kalimat gerak. Secara keseluruhan baik kostum, ragam, gerak, iringan dan struktur bentuk sajiannya, bahwa Tari Asmara Hastungkara adalah karya tari dengan gaya Yogyakarta. Namun dalam sajiannya kesan yang hadir adalah tari pasihan gaya Surakarta dikarenakan kemampuan penari yang berlatar belakang tari gaya Surakarta. Pada bagian muryani busana dan beksan jogedan mengadopsi gerakgerak gaya Surakarta, hal ini yang menjadi ciri tersendiri bagi Tari Pasihan Asmara Hastungkara.

\section{Kepustakaan}

Argananto, Selo. 2021. "Bentuk Tari Pasihan Asmara Hastungkara Karya Slamet.” Institut Seni Indonesia Surakarta.

Jazuli, M. 1994. Telaah Teoritis Seni Tari. Semarang: IKIP Semarang Press.

Langer, Suzanne K. 1988. Problematika Seni. Bandung: ISBI Bandung.

Maryono. 2015. Analisa Tari. Surakarta: ISI Press.

Prawiroatmodjo, S. 1994. Bausastra Jawa. Surakarta: Yayasan Djojobojo.

Slamet. 2016. Melihat Tari. Sukoharjo: Citra Sains.

Supriyanto. 1999. “Tari Golek Ayun-Ayun Gaya Yogyakarta Sebuah Konsep Pembentukan.” Surakarta.

Wardhani, A.G. 2009. "Struktur Dan Fungsi Tari Budi Tani Dalam Acara Syawalan Dukuh Palagan, Desa Lencoh, Kecamatan Selo, Boyolali." Institut Seni Indonesia Surakarta.

Wibowo, Fred. 1981. Mengenal Tari Klasik Gaya Yogyakarta. Yogyakarta: Dewan Kesenian Provinsi Daerah Istimewa Yogyakarta. 